\title{
PROTECTIVE EFFECT OF MONTELUKAST AGAINST PENTYLENETETRAZOLE- INDUCED ACUTE SEIZURES AND KINDLING IN MICE
}

\author{
Zaki Y. Abdel-kader, Nadia E.A. Khorshid, Dalia M. Abd El motteleb and \\ Nisreen E. Elwany \\ Clinical Pharmacology Department, Faculty of Medicine, Zagazig University
}

ABSTRACT

Background: Montelukast, a selective reversible cysteinyl leukotriene1 (CysLT1) receptor antagonist, is used in treatment of asthma, exercise induced-bronchospasm, allergic rhinitis and urticaria. It was shown to protect against cerebral ischemia/reperfusion injury. Objectives: To examine the possible anticonvulsant effect of montelukast, either alone or in combination with a known antiepileptic drug "valproate" against pentylenetetrazole (PTZ)-induced seizures. Methods: 112 adult male Swiss albino mice were used in the study and divided into two main groups, each containing 5 subgroups (Gp). The first main group "acute PTZ model (PTZ-a)" contains: Gp1 "vehicle-treated group" was injected with saline (10 ml/kg, intraperitoneally "i.p." in a single dose ), Gp2 "acute PTZ-control" injected with a single dose of PTZ (60 mg/kg, i.p.), Gp3 injected with valproate $(50 \mathrm{mg} / \mathrm{kg}$, i.p.) 30 minutes before PTZ, Gp4 injected with a single dose of montelukast (10 mg/kg, i.p.) 30 minutes before PTZ and Gp5 injected with both montelukast and valproate 30 minutes before PTZ administration. The second main group "kindling model (PTZ-k)" contains: Gp1 was injected with saline (i.p.) every other day for 17 days, Gp2 "PTZ-kindled control" received 9 PTZ injections in a dose of (40 mg/kg, i.p.) on alternate days for 17 days, Gp3 injected with valproate $(50 \mathrm{mg} / \mathrm{kg}$, i.p.) for 17 days, 30 minutes before PTZ, Gp4 daily injected with montelukast $(10 \mathrm{mg} / \mathrm{kg}$, i.p.) for 17 days 30 minutes before PTZ and $\mathrm{Gp} 5$ received both montelukast $(10 \mathrm{mg} / \mathrm{kg}$, i.p.) and valproate $(50 \mathrm{mg} / \mathrm{kg}$, i.p.) daily for 17 days, 30 minutes before administration of PTZ. Results: Single and repeated PTZ administration produced stage 4 seizures associated with a significant reduction in the brain level of reduced glutathione (GSH), concomittent with significant elevation in the brain levels of malondialdehyde (MDA), inteleukin1 $\beta$ (IL1 $\beta$ ), tumor necrosis factor $\alpha$ (TNF $\alpha$ ) and leukotriene D4 (LtD4). The use of valproate alone and its combination with montelukast suppressed the incidence of stage 4 seizures in acute PTZ induced convulsion while montelukast, valproate and their combination decreased the percentage of animals reaching stage 4 seizures in kindled mice. In both PTZ acute and kindled models, montelukast, valproate and their combined administration significantly elevated brain level of GSH and significantly decreased brain levels of MDA, IL1 $\beta$, TNF $\alpha$ and LtD4 as compared to PTZ control groups. Interestingly, co-administration of valproate and montelukast resulted in a significant elevation in the brain level of GSH concomitant with a significant reduction in the brain levels of MDA, IL1 $\beta$, TNF $\alpha$ and LtD4 as compared to each of the valproate and the montelukast groups in both models. Conclusion: Montelukast, either alone or in combination with valproate protects against PTZ induced seizures via blockade of leukotreine receptors \& amelioration of oxidative stress and inflammatory cascades.

Key words: Montelukast, PTZ., Seizures, Valproate.

Corresponding author: Nisreen Alnagy

Tel: 01286405904

Received: 7 October 2015

Email: nisreenelwany@yahoo.com

Accepted: 26 October 2015

\section{INTRODUCTION}

E pilepsy is a chronic neurological disorder characterized by repeated seizures resulted from excessive neuronal discharge ${ }^{[1]}$. The currently used antiepileptic drugs provide a symptomatic antiseizure effect without effective prophylaxis or cure. Furthermore, a wide range of adverse effects are associated with their long term use and limit their compliance $^{[2]}$. Therefore, a need for new antiepileptic drug with better compliance is a promising target. Montelukast, a selective reversible CysLT1 receptor antagonist was shown to reduce ischemia reperfusion (I/R)induced oxidative damage in the kidney and intestine $^{[3]}$. Several studies have also demonstrated the neuroprotective effects for montelukast in various neurodegenerative conditions such as acute and chronic ischemic brain injury ${ }^{[4]}$.

Increased inflammatory mediators (IL1 $\beta, \quad$ TNF $\alpha$ ) and LtD4 are observed following epileptogenic insult and are thought to be implicated in seizure development ${ }^{[5]}$, possibly by modulating GABA and glutamate homeostasis $^{[6,7]}$ and blood brain barrier (BBB) breakdown that leads to leakage of albumin and $\mathrm{IgG}$ into the brain. Albumin via activation of the transforming growth factor $\beta$ (TGF)- $\beta$ pathway, leads to increased neural excitability through down-regulation of inward rectifier potassium channel (Kir4.1) and glutamate transporter $^{[8]}$. Moreover, LtD4 receptor activation is reported to be associated with activation of phosphoinositide-3-kinase (PI-3$\mathrm{K})$, extracellular receptor kinase (ERK), mitogen-activated-protein- kinase (MAPK), 
NF-kB, TNF $\alpha$ and matrix-metalloproteinases9 (MMP-9) pathway. These pathways are suggested to participate in the pathophysiological seizure propagation ${ }^{[1]}$.

The current work aimed to study the possible protective effect of montelukast and its combination with valproate against PTZinduced acute and kindled seizures, and to investigate the possible mechanism(s) of action.

\section{Animals \\ MATERIALS AND METHODS}

112 adult male Swiss albino mice 8 weeks old weighing 15-35 g were used in the current study. Animals were purchased from the Faculty of Veterinary Medicine, Zagazig University, Egypt. Mice were allowed standard pellet diet and tap water ad libitum before, during one week of acclimatization period, and through the whole experimental period. They were kept at a constant temperature $\left(23 \pm 2^{\circ} \mathrm{C}\right)$, humidity $(60 \pm 10 \%)$ and a light/ dark (12 h:12 h) cycle. The animals were randomly assigned to experimental groups. Each mouse was used only once and all tests were performed between 8.00 and $15.00 \mathrm{~h}$. The experiment was performed in the pharmacology department laboratory, faculty of medicine, Zagazig University. Experimental design and animal handling were performed in accordance with protocols approved by the local experimental ethics committee guidelines of the Egyptian Society of Neuroscience, the Ethical Committee of the Faculty of Medicine, Zagazig University, for Animal Use and the guidelines of the US National Institutes of Health

on animal care.

\section{Experimental protocol}

The animals were divided into two main groups, each containing 5 subgroups (Gp). In the first main group "acute PTZ model": Gp1 (n: 8) "vehicle-treated subgroup" was injected with saline $(10 \mathrm{ml} / \mathrm{kg}$, i.p. $), \mathrm{Gp} 2$ (n:12) "acute PTZ-control subgroup" injected with a single dose of PTZ $(60 \mathrm{mg} / \mathrm{kg} \text {, i.p. })^{[9]}$, Gp3 (n:12) "valproate subgroup" injected with a single dose of valproate $(50 \mathrm{mg} / \mathrm{kg}, \text { i.p. })^{[10]}$ 30 minutes before PTZ, Gp4 (n: 12) "montelukast subgroup" injected with a single dose of montelukast $(10 \mathrm{mg} / \mathrm{kg}$, i.p. 30 minutes before PTZ ${ }^{[11]}$ and Gp5 (12 animals) "montelukast and valproate subgroup" injected with both montelukast $(10 \mathrm{mg} / \mathrm{kg}$, i.p. $)$ and valproate $(50 \mathrm{mg} / \mathrm{kg}$ i.p. $)$ once 30 minutes before PTZ. In the second group "PTZinduced kindling": Gp1 (n: 8) "vehicle-treated subgroup" was injected with saline $(10 \mathrm{ml} / \mathrm{kg}$, i.p.) every other day for 17 days, Gp2 (n:12) "PTZ-kindled control subgroup" received nine PTZ injections in a dose of $(40 \mathrm{mg} / \mathrm{kg}$, i.p. $)$ on alternate days for 17 days $^{[12]}, \mathrm{Gp3}$ (n: 12) "valproate subgroup" daily injected with valproate $(50 \mathrm{mg} / \mathrm{kg}$, i.p.) for 17 days 30 minutes before PTZ, Gp4 (n: 12) "montelukast subgroup" daily injected with montelukast (10 $\mathrm{mg} / \mathrm{kg} / \mathrm{d}$, i.p.) for 17 days 30 minutes before PTZ and Gp5 (n: 12) "montelukast and valproate subgroup" injected with both montelukast $(10 \mathrm{mg} / \mathrm{kg}$, i.p.) and valproate $(50$ $\mathrm{mg} / \mathrm{kg}$, i.p.) daily for 17 days 30 minutes before PTZ (Table 1). All drugs were dissolved in saline just before injection. After injections, the animals were observed for 20 minutes in Plexiglas cages. Five seizure stages were recorded: stage 0 "no response"; stage 1 "ear and facial twitching"; stage 2 "convulsive waves through the body without rearing"; stage 3 "myoclonic jerks, upright position"; stage 4 "clonic-tonic convulsions, turn over into side position" and stage 5 "generalized clonic-tonic convulsions, loss of postural control" $^{[12]}$. The maximum response reached was recorded in each mouse. The animals that exhibited convulsions after the first three injections, as well as the dead animals were excluded from this study. Kindling was achieved when mice had stage 4 seizures on three sequential PTZ injections throughout the experimental period. The percentage of animals at each seizure stage was calculated in each group $^{[13] \text {. }}$ 
Table 1: Experimental protocol showing the two main groups and subgroups

\begin{tabular}{|c|c|c|}
\hline $\begin{array}{l}\text { Acute PTZ } \\
\text { subgroups }\end{array}$ & No. & Drugs used \\
\hline Gp1 & 8 & Saline (10ml/kg, i.p.) \\
\hline $\mathrm{Gp} 2$ & 12 & PTZ single dose (60mg/kg, i.p.) \\
\hline Gp3 & 12 & $\begin{array}{l}\text { Valproate }(50 \mathrm{mg} / \mathrm{kg} \text {, i.p. }) 30 \mathrm{~min} \\
\text { before PTZ. }\end{array}$ \\
\hline Gp4 & 12 & $\begin{array}{l}\text { Montelukast }(10 \mathrm{mg} / \mathrm{kg} \text {, i.p. } 30 \mathrm{~min} \\
\text { before PTZ. }\end{array}$ \\
\hline Gp5 & 12 & $\begin{array}{l}\text { Both montelukast and valproate } 30 \\
\text { min before PTZ. }\end{array}$ \\
\hline $\begin{array}{l}\text { Chronic } \\
\text { PTZ } \\
\text { subgroups } \\
\end{array}$ & No. & Drugs used \\
\hline Gp1 & 8 & $\begin{array}{l}\text { Saline }(10 \mathrm{ml} / \mathrm{kg} \text {, i.p. }) \text { every other } \\
\text { day for } 17 \text { days. }\end{array}$ \\
\hline Gp2 & 12 & $\begin{array}{l}\text { PTZ }(40 \mathrm{mg} / \mathrm{kg} \text {, i.p.) on alternate } \\
\text { days for } 17 \text { days }\end{array}$ \\
\hline Gp3 & 12 & $\begin{array}{l}\text { Valproate }(50 \mathrm{mg} / \mathrm{kg} \text {, i.p.) every } \\
\text { day for } 17 \text { days } 30 \mathrm{~min} \text { before PTZ. }\end{array}$ \\
\hline Gp4 & 12 & $\begin{array}{l}\text { Montelukast }(10 \mathrm{mg} / \mathrm{kg} \text {, i.p) every } \\
\text { day for } 17 \text { days } 30 \mathrm{~min} \text { before PTZ. }\end{array}$ \\
\hline Gp5 & 12 & $\begin{array}{l}\text { Both montelukast and valproate } \\
\text { every day for } 17 \text { days } 30 \text { min } \\
\text { before PTZ. }\end{array}$ \\
\hline
\end{tabular}

Biochemical assays

Eight mice from each group were euthanized by decapitation $24 \mathrm{~h}$ after the acute and the last PTZ administration ${ }^{\mathbf{1 3}}$. Their brains were quickly removed in liquid nitrogen. The whole brain was homogenized in ice-cold saline for estimation of TNF- $\alpha$, IL- $1 \beta$, MDA, GSH, and LD4. Brain GSH was assessed using colorimetric assay kit according to Beutler et al. ${ }^{[14]}$ and values were expressed as mMol per milligram $(\mathrm{mg})$ of protein. MDA was measured as described by Okhawa et al. ${ }^{[15]}$ Its values were expressed as (mmol/mg ptn). Brain IL-1 $\beta$, TNF- $\alpha$, and LtD4 were estimated utilizing enzyme linked immunosorbant assay (ELISA) kits purchased from (R\&D system Quantitative USA), CUSABIO Bender Med Systems, USA), and results were expressed as picograms per milligram protein $(\mathrm{pg} / \mathrm{mg} \mathrm{ptn})$ for IL- $1 \beta$ and TNF- $\alpha$, as nanograms per milligram protein (ng/mg ptn), for LtD $4^{[16-18]}$.

\section{Statistical Analysis}

The obtained variables were tabulated as mean $\pm \mathrm{SE}$ (standard error of the mean). Comparison between different groups were made using one way analysis of variances test (one-way ANOVA) followed by Post-Hoc (least significant difference "LSD") tests as described by Armitage and Berry ${ }^{[19]}$. The categorical variables were expressed as a number percentage. Percent of categorical (ordinal variables were compared using Chisquare test for trend). The differences were considered to be significant when $\mathrm{p}<0.05$. Statistical package of social sciences (SPSS) computer software (version 16) was used to carry out the statistical analysis.

\section{RESULTS}

\section{Pharmacological results}

In acute PTZ model, administration of valproate and its combination with montelukast protected $58.3 \%$ and $91.7 \%$ of mice respectively from reaching stage 4 seizures ( $p$ <0.05). (Table2). In kindled model, the animals experienced seizures starting from the $4^{\text {th }}$ dose of PTZ $\left(7^{\text {th }}\right.$ day of the experiment), but all mice in the PTZ kindled control subgroup reached stage $4 / 5$ at the $6^{\text {th }}$ injection of PTZ $\left(11^{\text {th }}\right.$ day of the experiment) and lasted thereafter. The protective effect of valproate started from the $9^{\text {th }}$ day of the experiment, where only $41.6 \%$ of the animals reached stage 4. This percentage decreased to $33.3 \%$ on the last day of the experiment. The protective effect of montelukast started from the $13^{\text {th }}$ day of the experiment; where $66.7 \%$ of the animals reached stage 4 and this percentage lasted till the last day of the experiment. Interestingly, none of the animals in the combination group reached stage 4 during the course of the experiment (Table 3). On the last day, repeated administration of valproate, montelukast and their combination protected $66.7 \%, 33.3 \%$ and $100 \%$, respectively, of the animals from reaching stage 4 ( $p<0.05)$. (Table 4$)$.

\section{Biochemical results}

Compared to normal animals, PTZacute (PTZ-a) and PTZ-kindling (PTZ-k) caused a significant reduction $(\mathrm{p}<0.05)$ in brain GSH by $59 \%$ and $67 \%$ respectively. Moreover, both PTZ dose regimens significantly $(\mathrm{p}<0.05)$ increased brain MDA by $312 \%$ (PTZ-a) and $460 \%$ (PTZ-k) respectively.

In PTZ-a, pretreatment with valproate, montelukast or their combination significantly (p <0.05) increased brain GSH by $38.2 \%$, $73.4 \%$, and $96.6 \%$, respectively, as compared to PTZ control subgroup. Furthermore, valproate, montelukast and their combination significantly $(\mathrm{p}<0.05)$ decreased the elevated 
brain MDA by $29.5 \%, 36.4 \%, \quad 63.5 \%$ respectively, as compared to acute PTZ control group. In kindled mice, valproate, montelukast and their combination significantly $(\mathrm{p}<0.05)$ increased $\mathrm{GSH}$ by $78 \%, 95.5 \%, 176 \%$, as compared to PTZ control group. They also significantly $(\mathrm{p}<0.05)$ decreased brain MDA by $38 \%, 41 \%, 58.8 \%$ respectively. (Figures $1,2)$.

Additionally, both PTZ dose regimens (acute and kindling) significantly ( $\mathrm{p}<0.05$ ) elevated brain IL1 $\beta$, TNF $\alpha$ and LtD4 by $165 \%$, $205 \%, 164 \%, 194 \%, 333 \%$ and $402 \%$ respectively as compared to normal group (Figures 3-5). In acute PTZ model, pretreatment with valproate, montelukast or their combination significantly $(p<0.05)$ decreased the elevated brain levels of IL1 $\beta$ by $29.9 \%, 30.4 \%$, and $57 \%$, respectively, as compared to acute PTZ control subgroup. Valproate, montelukast and their combination further caused a significant $(\mathrm{p}<0.05)$ reduction in brain $\mathrm{TNF} \alpha$ levels by $32 \%, 37 \%$, and $56 \%$ as well as LtD4 by $31 \%, 33 \%$, and $62 \%$ respectively, as compared to acute PTZ control group. In PTZ kindled model, valproate, montelukast or their combination significantly ( $\mathrm{p}<0.05$ ) decreased brain IL1 $\beta$ by $24 \%, 29 \%$, and $39 \%$, respectively, as compared to chronic PTZ control group. Moreover, the used drugs significantly $(\mathrm{p}<0.05)$ reduced the brain TNF $\alpha$ by $35 \%, 30 \%$, and $45 \%$, respectively, as well as LtD 4 by $38.5 \%, 38.8 \%$ and $60 \%$, respectively.

Table 2: Percentage of reduction of stage 4 seizures induced by single dose of valproate ( $50 \mathrm{mg} / \mathrm{kg}$, i.p.), montelukast $(10 \mathrm{mg} / \mathrm{kg}$, i.p.) or their combination in acute PTZ model in mice

\begin{tabular}{lcccc}
\hline & Control & Valproate & Monteleukast & Combination \\
\hline Percentage & & & & \\
& $0 \%$ & $58.3 \%$ & $16.5 \%$ & $91.7 \%$ \\
\hline
\end{tabular}

Values with different capital letters are significantly different $(\mathrm{p}<0.05)$

Table (3): Effects of valproate (50mg/kg, i.p.), montelukast (10mg/kg i.p), and their combination (every day for 17 days) on seizure stage 4 , during the course of kindling $(k)$ in mice $(n=12)$

\begin{tabular}{|c|c|c|c|c|}
\hline & Control & Valproate & Monteleukast & Combination \\
\hline $4^{\text {th }}$ dose (day7) & $50 \%$ & $50 \%$ & $50 \%$ & $0 \%$ \\
\hline $5^{\text {th }}$ dose (day 9) & $50 \%$ & $41.6 \%$ & $58.3 \%$ & $0 \%$ \\
\hline $6^{\text {th }}$ dose (day11) & $100 \%$ & $41.6 \%$ & $75 \%$ & $0 \%$ \\
\hline $7^{\text {th }}$ dose (day13) & $100 \%$ & $41.6 \%$ & $66.7 \%$ & $0 \%$ \\
\hline $8^{\text {th }}$ dose (day 15) & $100 \%$ & $33.3 \%$ & $66.7 \%$ & $0 \%$ \\
\hline $9^{\text {th }}$ dose (day 17$)$ & $100 \%$ & $33.3 \%$ & $66.7 \%$ & $0 \%$ \\
\hline
\end{tabular}

Table 4: Percentage of reduction induced by valproate $(50 \mathrm{mg} / \mathrm{kg})$, montelukast $(10 \mathrm{mg} / \mathrm{kg})$ or their combination (every day for 17 days) on stage 4 seizure in the last day of the experiment in PTZ kindling (k) model in mice $(\mathrm{n}=12)$

\begin{tabular}{ccccc}
\hline \multirow{2}{*}{ Stage of seizure } & Control & Valproate & Monteleukast & Combination \\
\hline Percentage & $0 \%$ & & & $100 \%$ \\
& $\mathbf{A}$ & $66.7 \%$ & $33.3 \%$ & $\mathbf{C}$ \\
\hline
\end{tabular}

Values with different capital letters are significantly different $(p<0.05)$

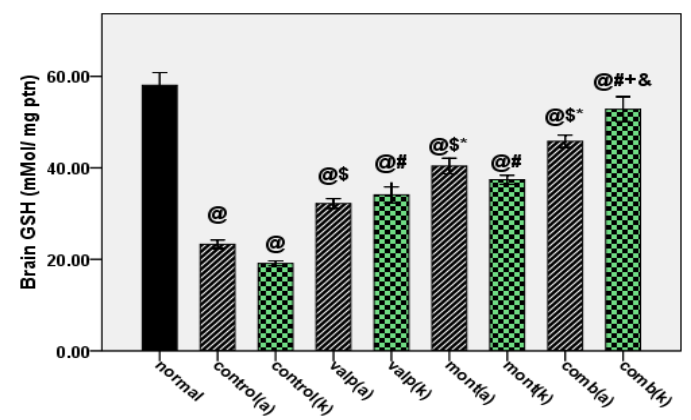

Fig. 1: showing comparison between different groups regarding brain GSH in PTZ-acute(a) and kindling (k) models. Values are means of 8 mice \pm SEM. @ P $<0.05$ compared to normal group, $\$ \mathrm{P}<0.05$ compared to PTZ-acute control group, $* \mathrm{P}<0.05$ compared to valproate group, $=\mathrm{P}<0.05$ compared to montelukast (a) group, \#P $<0.05$ compared to

PTZ-kindled control, $+\mathrm{P}<0.05$ compared to valproate $(\mathrm{k})$ group, \& $\mathrm{P}<0.05$ compared to montelukast (k). 


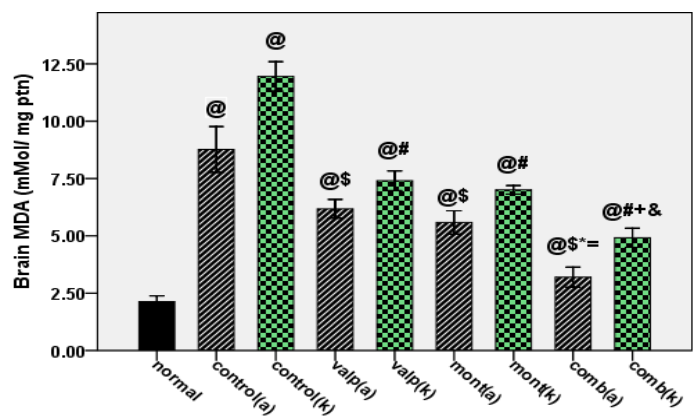

Fig. 2: showing comparison between different groups regarding brain MDA in PTZ-acute(a) and kindling(k) models. Values are means of 8 mice \pm SEM. @ P $<0.05$ compared to normal group, $\$ \mathrm{P}<0.05$ compared to PTZ-acute control group, $* \mathrm{P}<0.05$ compared to valproate group, $=\mathrm{P}<0.05$ compared to montelukast (a) group, \#P $<0.05$ compared to

PTZ-kindled control, +P $<0.05$ compared to valproate (k) group \& $\mathrm{P}<0.05$ compared to montelukast (k).

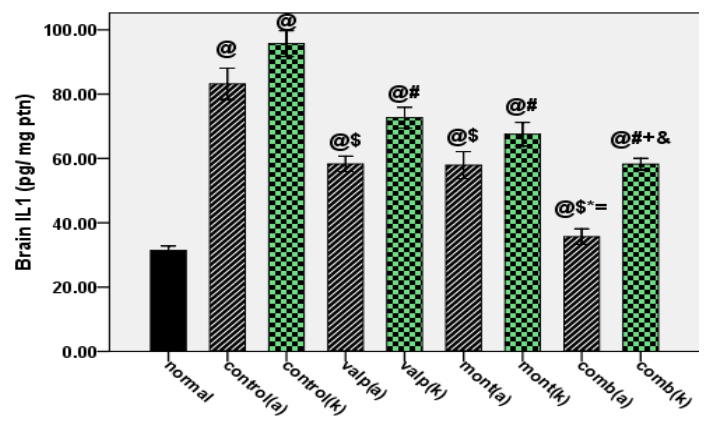

Fig.3: showing comparison between different groups regarding brain IL1- $\beta$ in PTZ-acute(a) and kindling(k) models. Values are means of 8 mice \pm SEM. @ P $<0.05$ compared to normal group, \$ $\mathrm{P}<0.05$ compared to PTZ-acute control group, ${ }^{*} \mathrm{P}<0.05$ compared to valproate group, $=\mathrm{P}<0.05$ compared to montelukast (a) group, \#P $<0.05$ compared to

PTZ-kindled control, $+\mathrm{P}<0.05$ compared to valproate $(\mathrm{k})$ group, \& $\mathrm{P}<0.05$ compared to montelukast (k).

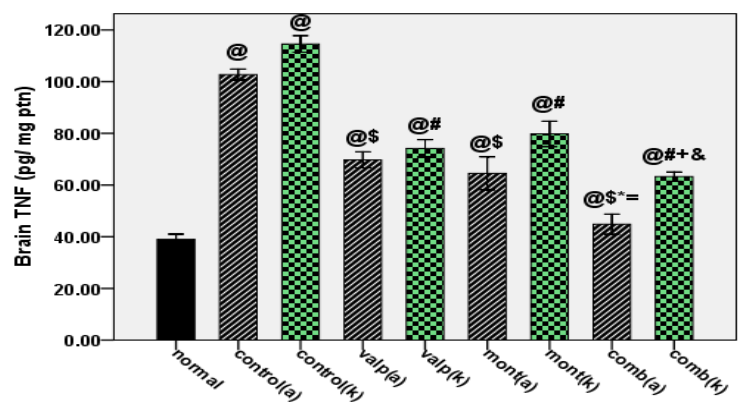

Fig. 4: showing comparison between different groups regarding brain TNF- $\alpha$ in PTZ-acute(a) and kindling (k) models. Values are means of 8 mice \pm SEM; statistical comparisons are carried out using one-way ANOVA followed by posthoc tests using LSD method. @ P < 0.05 compared to normal group, \$ P <0.05 compared to PTZ-acute control group, $* \mathrm{P}<0.05$ compared to valproate group, $=\mathrm{P}<0.05$ compared to montelukast (a) group, \#P $<0.05$ compared to PTZkindled control, $+\mathrm{P}<0.05$ compared to valproate $(\mathrm{k})$ group, \& $\mathrm{P}<0.05$ compared to montelukast $(\mathrm{k})$.

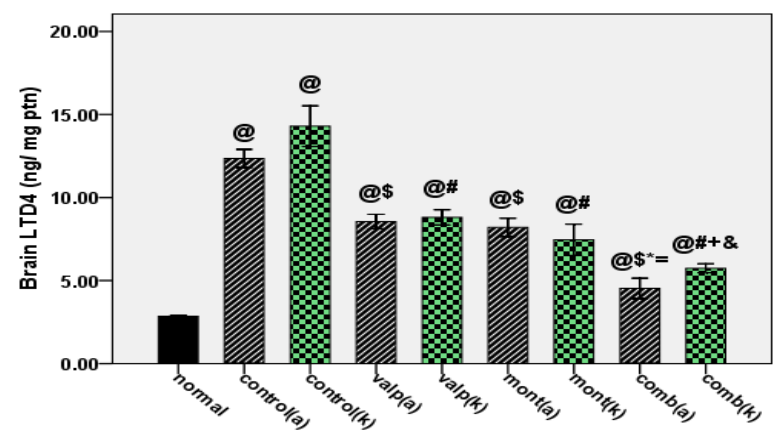

Fig. 5: showing comparison between different groups regarding brain LtD4 in PTZ-acute (a) and kindling (k) models. Values are means of 8 mice \pm SEM. @ P $<0.05$ compared to normal group, $\$ \mathrm{P}<0.05$ compared to PTZ-acute control group, $* \mathrm{P}<0.05$ compared to valproate group, $=\mathrm{P}<0.05$ compared to montelukast (a) group, \#P $<0.05$ compared to

PTZ-kindled control, $+\mathrm{P}<0.05$ compared to valproate (k) group, \&P $<0.05$ compared to montelukast (k). 


\section{DISCUSSION}

The present work revealed that all animals injected with PTZ (either a single or repeated doses) reached stage $4 / 5$ clonic convulsions. These were associated with a significant reduction in brain GSH and significant elevation in brain MDA in both animal models as compared to normal vehicletreated subgroups.

It is postulated that oxidative stress produced by reactive oxygen species (ROS) generation is likely implicated in the initiation and progression of epilepsy ${ }^{[20]}$. Our results coincide with Cárdenas-Rodríguez et al. ${ }^{[21]}$ who stated that there is a significant elevation of lipid peroxidation in association with a significant decrease in the antioxidant enzymes and reduced glutathione (GSH) levels in whole brain of acute PTZ and PTZ-kindled animals.

One explanation how oxidative stress occurs during epileptogenesis is that seizuresassociated glutamate exitotoxicity and $\mathrm{N}$ methyl D-aspartate (NMDA) receptor overactivation result in elevation of intraneuronal $\mathrm{Ca}^{2+}$ and decrease of intracellular antioxidant GSH due to cystine deprivation caused by the binding of glutamate to cysteine transporter ${ }^{[22]}$. ROS could be produced as a result of calcium-mediated activation of xanthine oxidase, protease and nuclease enzymes that disrupt the cellular antioxidant system ${ }^{[23]}$. Moreover, $\mathrm{Ca}^{2+}$ dependent activation of phospholipase A2 releases arachidonic acid yielding free radicals through metabolism by lipoxygeneses ${ }^{\mathbf{2 1}}$. Likewise, calcium mediated mitochondrial damage plays a key role in ROS production. On the other hand, ROS are thought to be implicated in excitotoxicity and apoptosis that contribute to seizure-induced brain damage ${ }^{[24]}$. Free radicals in turn can further increase glutamate concentration and diminish GABA through inactivation of glutamine synthase, inhibition of glutamate decarboxylase and inactivation of glutamate transporter ${ }^{[25]}$. Additionally, ROS may activate NFkB, leading to production of pro-inflammatory cytokines such as IL-1, IL-6 and TNF- $\alpha$, which in turn enhance inflammation and, therefore, the generation of other reactive species $^{[26]}$.
In the current work, a single or chronic PTZ administration resulted in elevation of the brain levels of inflammatory cytokines (IL1 $\beta$ and TNF- $\alpha$ ). These findings are in agreement with those reported by Vezzani et al. ${ }^{[5]}$ who found that increased levels of inflammatory cytokines are detected in animal models of epilepsy induced by chemoconvulsants or by electrical stimulation ${ }^{[13]}$. Moreover, Gómez, et al. ${ }^{[27]}$ disclosed elevated cytokines level in the serum and cerebrospinal fluid of epileptic patients. The elevated levels of brain inflammatory mediators documented in the current work may indicate their role in seizure induction or propagation. In line with this view, IL-1 $\beta$ receptor antagonist inhibited PTZinduced seizures, kindling development in rats $^{[28]}$. IL-1 $\beta$ through binding to IL-1R1 and $\mathrm{TNF} \alpha$ activate transcription factors such as $\mathrm{NF}-\kappa \mathrm{B}$ which regulates the synthesis of chemokines, cytokines, enzymes (for example, CoX-2) and receptors (for example, TLRS, IL$1 \mathrm{R} 1$, and TNF p55 and p75 receptors) that are involved in epileptogenesis ${ }^{[29]}$. NF- $\kappa B$ activation can also induce the generation of neurotoxic free radicals; resulting in neuronal apoptosis $^{[30]}$. In addition, occupancy of IL-1R1 or TLRS results in activation of src tyrosine kinase, mitogen activated protein kinases (MAPK) system with subsequent induction of neuronal cyclic adenosine monophosphate (cAMP) response element-binding protein ${ }^{[31]}$. These pathways result in phosphorylation of voltage-dependent and receptor-coupled ion channels, and increasing the neuronal excitability $^{[31]}$. For example, the proconvulsant activity of IL-1 $\beta / \mathrm{IL}-1 \mathrm{R} 1$ complex is mediated by phosphorylation of the NMDA receptor $2 \mathrm{~B}$ subunit via src, with subsequent neuronal calcium influx and excitotoxicity ${ }^{[5]}$. Furthermore, the phosphorylation of the NR2B subunit seems to prevent endocytosis and protect this subunit from calpain $\left(\mathrm{Ca}^{2+}\right.$ dependant ptotease) degradation ${ }^{[32]}$.

$$
\text { Additional mechanisms }
$$

of hyperexcitability induced by IL- $1 \beta$ and TNF- $\alpha$ include cytokine-mediated glutamate release from astrocytes, inhibition of glial glutamate reuptake (through inhibition of glutamate transporter GLUT-1) ${ }^{\mathbf{5}}$ and increasing the glutamate receptor subunit expression ${ }^{[29]}$. IL$1 \beta$ and TNF- $\alpha$ can further decrease the GABA- 
mediated inhibition in inflamed brain tissue through their ability to reduce GABA-A receptors expression or induce their endocytosis at neuronal membranes ${ }^{[33]}$.

The results of the current study showed that acute and chronic PTZ injection induced a significant elevation in the brain level of LtD4. Formation of leukotrienes is initiated by 5LOX-mediated conversion of arachidonic acid to 5(S)-hydroperoxy-eicosatetraenoic acid, which is further transformed to LtA4. This unstable epoxide can be further hydrolyzed to LtB4 ${ }^{[34]}$. Alternatively, LtA4 may be converted to LtC4 which get transformed by gamma glutamyl transpeptidase to LtD4 and LtE4 ${ }^{[35]}$.

The implication of leukotrienes in epilepsy is supported by Shin, et al. ${ }^{[36]}$ who elucidated that phenidone which decreased leukotriene production, protected against kainate-induced seizures. At the same time, phenidone dose dependently attenuated the KA-induced oxidative stress in hippocampal neurons. Similarly, Liu, et al. ${ }^{[37]}$, have shown that zileuton, a 5-LOX inhibitor, decreases pilocarpine induced seizures in rats.

In addition, Vezzani and Granata ${ }^{[31]}$, revealed that TNF- $\alpha$ stimulates arachidonic acid release and induces the transcription of inflammatory genes that increase LOX enzyme expression ${ }^{[13]}$. That effect was confirmed in the present work, where PTZ administration resulted in elevation of mice brain TNF- $\alpha$ and LtD4 in both models.

In the present study, valproate administration was observed to protect against PTZ-induced acute seizures and kindling, hampered brain oxidative stress and reduced the brain levels of inflammatory mediators. The anti-oxidant effect of valproate is attributed to its free radical scavenging ability $^{[38]}$, enhancement of enzymatic as well as non-enzymatic antioxidants (Superoxide dismutase, catalase, vitamin $\mathrm{E}$, and reduced glutathione $)^{[39]}$. Furthermore, blockade of NMDA receptor and $\mathrm{Na}^{+}$channel-mediated glutamate release and excitotoxicity in cerebral nerve endings ${ }^{[27]}$ may be an additional contributing factor in ROS production inhibition.

Moreover, by inhibiting histone deacetylase (HDACs), valproate has the ability to activate the expression of genes targeting antioxidant enzymes (e.g. SOD), and induces several neuroprotective proteins such as angiogenin (ANG), brain-derived neurotrophic factor (BDNF), endothelial cell growth factor (ECGF1) and ganglia cell-derived neurotrophic factor (GDNF) ${ }^{[40]}$. Additionally, Ximenes et al. ${ }^{[41]}$ referred the valproatesuppressing effect on inflammatory mediators to the inhibition of NF- $\mathrm{NB}$.

The present work showed that montelukast alone failed to protect against PTZ-induced acute seizures which may explained on the basis that acute seizures are blocked mainly by agents either acting at the $\mathrm{GABA}_{\mathrm{A}}$ receptor or agents that reduce T-type $\mathrm{Ca}^{2+}{ }^{2}$ currents ${ }^{[42]}$ rather than those affecting oxidative stress and inflammatory cascades as occur in kindling induced seizure ${ }^{[43]}$ while repeated administration of montelukast, protected the animals against PTZ-induced kindling. The observed anti-seizure effect of montelukast could be attributed to its antioxidant property represented in elevation of GSH concomitant with reduction of the brain level of MDA. In line with our results, Ozturk, et al. ${ }^{[4]}$ documented an anti-oxidant effect of montelukast in ischemia/reperfused liver, intestine, kidney, testes and bladder models.

In both PTZ models, montelukast administration suppressed the brain levels of inflammatory mediators; IL1 $\beta, \mathrm{TNF} \alpha$ and $\mathrm{LtD} 4$, that was in line with those of Al-Amran, et al. ${ }^{[45]}$. Such effect could be attributed to the blockade of LTs enhancement effect on TNF- $\alpha$ induced cytokines production via $\mathrm{NF}-\kappa^{[46]}$ and the diminution of CysLTs-mediated calcium release and subsequently protein kinase C, MAP, and PI3K activation ${ }^{[47]}$. Interestingly, montelukast was reported to possess a range of secondary CysLT1Rindependent, anti-inflammatory activities, apparently unrelated to antagonism of CysLT1Rs. These include (i) inhibition of 5lipoxygenase (5-LOX) resulting in attenuation of production not only of cysLTs but also of $\mathrm{LtB} 4^{48}$, (ii) inhibition of histone acetyltransferase (HAT) inhibiting inflammatory genes expression ${ }^{49}$ and (iii) inhibition of cyclic nucleotide phosphodiesterases (PDEs) the accumulated 
cAMP through cAMP-dependent protein kinase $\mathrm{A}$ (PKA) promoting restoration of $\mathrm{Ca}^{2+}$ homeostasis ${ }^{50}$.

The observed potentiating effect of montelukast on the anticonvulsant action of valproate in both models was associated with a significant attenuation in oxidative stress markers and inflammatory mediators release, as compared to each of the valproate and to the montelukast groups in both PTZ models. In parallel with our results, Fleck et al. ${ }^{\mathbf{1 1}}$ showed that montelukast synergistically enhances the anticonvulsant effect of phenobarbital in an acute PTZ-induced seizure model in mice. A clinical study performed by Takahashi et al. ${ }^{\mathbf{5 1}}$, has shown that pranlukast (a CysLT receptor antagonist) add-on therapy in patients with intractable partial epilepsy reduced seizure frequencies.

\section{CONCLUSION}

The results of the current study clarify the role of oxidative stress, inflammatory cytokines and leukotrienes in acute seizures, as well as in the process of kindling, and favor the protective effect of montelukast coadministered with valproate against experimentally induced seizures.

\section{ABBREVIATIONS}

ANG: Angiogenin; BBB: Blood-brain barrier; BDNF:Brain-derived neurotrophic factor; cAMP: Cyclic adenosine monophosphate; COX: Cyclo-oxygenase enzyme; CysLt: Cysteinyl leukotriene; ECGF1: Endothelial cell growth factor; ERK: Extracellular receptor kinase; GABA: Gamma amino butyric acid; GDNF: Glial cellderived neurotrophic factor; GSH: Reduced glutathione; I/R: Ischemia reperfusion; IL-1 $\beta$ : Interleukin1 $\beta$; IL-1R: IL-1 receptor; Kir4.1: Inward rectifier potassium channel; LOX: Lipo-oxygenase; MAPK: Mitogen activated protein kinase; MDA: Malondialdehyde; MMP-9: Matrixmetalloproteinases-9; NFk $\beta$ : Nuclear factor kappa; NMDA: N-methyl-D-aspartic acid; PI3-K: Phosphoinositide-3-kinase; PKA,Protein kinase A; ROS: Reactive oxygen species; SOD: Superoxide dismutase; TGF- $\beta$ : Transforming Growth Factor- $\beta$; TLR: $\quad$ Toll like receptor; TNF- $\alpha$ : Tumor Necrosis Factor$\alpha ; \mathrm{n}$ : number of animals.

\section{REFERENCES}

1- Rehni AK, Singh TG. Modulation of leukotriene D4 attenuates the devel-opment of seizures in mice. Prostaglandins Leukot Essent Fatty Acids. 2011;85(2):97-106.

2- Cevik B, Solmaz V, Aksoy D, Erbas O. Montelukast inhibits pentylenetetrazol-induced seizures in rats. Med Sci Monit. 2015;21:869874.

3- Wu S, Zhu X, Jin Z, Tong X, Zhu L, Hong $\mathbf{X}$, et al. The protective role of montelukast against intestinal ischemia-reperfusion injury in rats. Sci Rep. 2015;5:15787.

4- Zhao R, Shi WZ, Zhang YM, Fang S, Wei E. Montelukast, a cysteinyl leukotriene receptor-1 antagonist, attenuates chronic brain injury after focal cerebral ischaemia in mice and rats. $\mathbf{J}$ Pharm Pharmacol. 2011;63:550-557.

5- Vezzani A, French J, Bartfai T, Baram TZ. The role of inflammation in epilepsy. Nat Rev Neurol. 2011;7(1):31-40.

6- Li G, Bauer S, Nowak M, Norwood B, Tackenberg B, Rosenow F, et al. Cytokines and epilepsy. Seizure. 2011;20(3):249-56.

7- Maroso M, Balosso S, Ravizza T, Liu J, Aronica E, Iyer AM, et al. Toll-like receptor 4 and high-mobility group box-1 are involved in ictogenesis and can be targeted to reduce seizures. Nat. Med. 2010;16:413-419.

8- Shimada T, Takemiya T, Sugiura H, Yamagata K. Role of inflammatory mediators in the pathogenesis of epilepsy. Mediators Inflamm. 2014;2014: ID 901902. 8 pages.

9- Uma Devi P, Pillai KK, Vohora D. Modulation of pentylenetetrazole-induced seizures and oxidative stress parameters by sodium valproate in the absence and presence of $\mathrm{N}$ acetylcysteine. Fundam. Clin. Pharmacol. 2006; 20: 247-253.

10- Zolkowska D, Kominek M, Florek-Łuszczki M, Kocharov SL, Luszczki JJ. Effects of N(morpholinomethyl)-p-isopropoxyphenyl succinimide on the protective action of different classical antiepileptic drugs against maximal electroshock-induced tonic seizures in mice. Pharmacol Rep. 2013;65(2):389-398.

11- Fleck J, Marafiga JR, Jesse AC, Ribeiro LR, Rambo LM, Mello CF. Montelukast potentiates the anticonvulsant effect of phenobarbital in mice: An isobolographic analysis. Pharmacol Res. 2015;94:34-41.

12- Ammon-Treiber S, Grecksch G, Angelidis C, Vezyraki P, Höllt V, Becker A. Pentylenetetrazol-kindling in mice overexpressing heat shock protein 70 . Naunyn- 
Schmiedeberg's Arch. Pharmacol. 2007;375:115-121

13- Abdallah DM. Anticonvulsant potential of the peroxisome proliferator-activated receptor $\gamma$ agonist pioglitazone in pentylenetetrazoleinduced acute seizures and kindling in mice. Brain Res. 2010;1351:246-253.

14- Beutler E, Duron O, Kelly BM. Improved method for the determination of blood glutathione. J Lab Clin Med. 1963;61:882-888.

15- Okhawa H, Ohishi N, Yagi K. Assay of lipid peroxides in animal tissue by thiobarbituric acid reaction. Anal Biochem. 1979;95:351-358.

16- Baskaya MK, Hu YG, Donaldson D, Maley M, Rao AM, Prasad MR, et al. Protective effect of the 5-lipoxygenase inhibitor AA-861 on cerebral edema after transient ischemia. J. Neurosurg. 1996;85:112-116.

17- Sims JE, Smith DE. The IL-1 family: regulators of immunity. Nat. Rev. Immunol. 2010;10(2):89-102.

18-Vilcek J, Lee TH. Tumor necrosis factor. New insights into the molecular mechanisms of its multiple actions. J. Biol. Chem. 1991;266(12):7313-7316.

19- Armitage P, Berry G. Statistical methods in medical research, $3^{\text {rd }}$ edition; pp 620. Blackwell Scientific Publications, Oxford. London, 1994.

20- Waldbaum S, Patel M. Mitochondria, oxidative stress, and temporal lobe epilepsy. Epilepsy Research. 2010;88, 23-45.

21- Cárdenas-Rodríguez $\mathrm{N}$, Coballase-Urrutia E, Rivera-Espinosa L, Romero-Toledo A, Sampieri A, Ortega-Cuellar D, et al. Modulation of antioxidant enzymatic activities by certain antiepileptic drugs (valproic acid, oxcarbazepine, and topiramate): evidence in humans and experimental models. Oxid Med Cell Longev. 2013:2013:598493.

22- Dillioglugil MO, Kir HM, Demir C, Ilbay G, Sahin D, Dillioglugil $O$, et al. Effect of pentylenetetrazole and sound stimulation induced single and repeated convulsive seizures on the MDA, GSH and NO levels, and SOD activities in rat liver and kidney tissues. Brain Res Bull. 2010;83(6):356-359.

23- Balkhi, H.M.; Gul,T.; Banday, M.Z.; Haq, E. (2014): Glutamate Excitotoxicity: An Insight into the Mechanism. International Journal of Advanced Research. 2(7): 361-373.

24- Suda S, Katsura K, Kanamaru T, Saito M, Katayama Y. Valproic acid attenuates ischemia-reperfusion injury in the rat brain through inhibition of oxidative stress and inflammation. European Journal of Pharmacology. 2013;707(1-3): 26-31.
25- Morimoto K, Fahnestock M, Racine RJ. Kindling and status epilepticus models of epilepsy: rewiring the brain. Progr Neurobiol. 2004;73:1-60.

26-Himmerich H, Bartsch S, Hamer H, Mergl $\mathbf{R}$, Schönherr J, Petersein $\mathrm{C}$, et al. Modulation of cytokine production by drugs with antiepileptic or mood stabilizer properties in anti-CD3- and anti-d40-stimulated blood in vitro. Oxid Med Cell Longev. 2014;2014:806162.

27-Gómez CD, Buijs RM, Sitges M. The antiseizure drugs vinpocetine and carbamazepine, but not valproic acid, reduce inflammatory IL$1 \beta$ and TNF- $\alpha$ expression in rat hippocampus. $\mathrm{J}$ Neurochem. 2014;130(6):770-779.

28- Maroso M, Balosso S, Ravizza T, Liu J, Bianchi ME, Vezzani A. Interleukin-1 type 1 receptor/Toll-like receptor signalling in epilepsy: the importance of IL-1beta and highmobility group box 1 . J Intern Med 2011;270:319-326.

29-Vezzani A, Aronica E, Mazarati A, Pittman QJ. Epilepsy and brain inflammation. Exp Neurol. 2013;244:11-21.

30- Hsu HC, Tang NY, Liu CH, Hsieh C L. Antiepileptic Effect of Uncaria rhynchophylla and Rhynchophylline Involved in the Initiation of c-Jun N-Terminal Kinase Phosphorylation of MAPK Signal Pathways in Acute Seizures of Kainic Acid-Treated Rats. Evid Based Complement Alternat Med. 2013:2013-961289.

31-Vezzani, A.; Granata, T. (2005):Brain inflammation in epilepsy: experimental and clinical evidence. Epilepsia. 46(11):1724-1743.

32-Vezzani A, Balosso S, Ravizza T. The role of cytokines in the pathophysiology of epilepsy. Brain, Behavior, and Immunity 2008;22:797803.

33-Balosso S, Ravizza T, Aronica E, Vezzani A. The dual role of TNF- $\alpha$ and its receptors in seizures. Exp Neurol. 2013;247:267-271.

34-Corey EJ, Marfat A, Goto G, Brion F. Leukotriene B. Total synthesis and assignment of stereochemistry, J. Am. Chem. Soc. 1980;102:7984-7985.

35-Lenz QF, Arroyo DS, Temp FR, Poersch AB, Masson CJ, Jesse AC, et al. Cysteinylleukotriene receptor (CysLT) antagonists decrease pentylenetetrazolinducedseizures and blood-brain barrier dysfunction. Neuroscience 2014;277:859-871.

36- Shin EJ, Jeong JH, Chung YH, Kim WK, Ko KH, Bach JH, et al. Role of oxidative stress in epileptic seizures. Neurochem Int. 2011;59(2):122-137. 
37- Liu, X.; Yang, Z.; Yin, Y.; Deng, X. (2014): Increased expression of Notch1 in temporal lobe epilepsy: animal models and clinical evidence. Neural Regen Res. 9(5):526-533.

38-Rajeshwari $T$, Raja $B$, Manivannan $J$, Silambarasan T, Dhanalakshmi T. Valproic acid prevents the deregulation of lipid metabolism and renal renin-angiotensin system in L-NAME induced nitric oxide deficient hypertensive rats. Environ Toxicol Pharmacol. 2014;37(3):936-945.

39-Cardinale JP, Sriramula S, Pariaut R, Guggilam A, Mariappan N, Elks CM, Francis J. HDAC inhibition attenuates inflammatory, hypertrophic, and hypertensive responses in spontaneously hypertensive rats. Hypertension 2010;56: 437- 444.

40- Jung KH, Han DM, Jeong SG, Choi MR, Chai YG, Cho GW. Proteomic analysis reveals KRIT1 as a modulator for the antioxidant effects of valproic acid in human bone-marrow mesenchymal stromal cells. Drug Chem Toxicol. 2015;38(3):286-292.

41- Ximenes JC, de Oliveira GD, Siqueira RM, Neves KR, Santos Cerqueira G, Correia AO, et al. Valproic acid: an anticonvulsant drug with potent antinociceptive and antiinflammatory properties. Naunyn Schmiedebergs Arch Pharmacol. 2013;386(7):575-587.

42-Löscher W. Animal models of epilepsy for the development of antiepileptogenic and diseasemodifying drugs. A comparison of the pharmacology of kindling and post-status epilepticus models of temporal lobe epilepsy. Epilepsy Res. 2002;50 (1-2):105-123.

43- Garcia Garcia ME, Garcia Morales I, Matías Guiu J. Experimental models in epilepsy. Neurologia 2010;25(3):181-188.

44- Ozturk H, Ozturk H, Gideroglu K, Terzi H, Bugdayci G. Montelukast protects against testes ischemia/reperfusion injury in rats. Can Urol Assoc J. 2010;4(3):174-179.

45- Al-Amran FG, Hadi NR, Hashim AM. Cysteinyl leukotriene receptor antagonist montelukast ameliorates acute lung injury following haemorrhagic shock in rats. Eur $\mathbf{J}$ Cardiothorac Surg. 2013;43(2):421-427.

46-Saad MA, Abdelsalam RM, Kenawy SA, Attia AS. Montelukast, a cysteinyl leukotriene receptor-1 antagonist protects against hippocampal injury induced by transient global cerebral ischemia and reperfusion in rats. Neurochem Res. 2015;40(1):139-150.

47-Al Saadi MM, Meo SA, Mustafa A, Shafi A, Tuwajri AS. Effects of Montelukast on free radical production in whole blood and isolated human polymorphonuclear neutrophils (PMNs) in asthmatic children. Saudi Pharm J. 2011;19(4):215-220.

48-Theron AJ, Steel HC, Tintinger GR, Gravett CM, Anderson R, Feldman C. Cysteinyl leukotriene receptor-1 antagonists as modulators of innate immune cell function. $\mathbf{J}$ Immunol Res. 2014;2014:608930.

49-Abdel Kawy HS. Antiinflammatory Effect of Montelukast versus Dexamethasone on a COPD Model induced by Chronic Exposure to Lipopolysaccharide in Guinea Pigs. EJBCP. 2012;2( 2):23-35.

50-Lau WK, Chow AW, Au SC, Ko WH. Differential inhibitory effects of CysLT(1) receptor antagonists on $\mathrm{P} 2 \mathrm{Y}(6)$ receptormediated signaling and ion transport in human bronchial epithelia. PLoS One. 2011;6(7):e22363.

51- Takahashi Y, Imai K, Ikeda H, Kubota Y, Yamazaki E, Susa F. Open study of pranlukast add-on therapy in intractable partial epilepsy. Brain Dev. 2013;35(3):236-244. 